\title{
A case of prenatal diagnosis of $18 p$ deletion syndrome following noninvasive prenatal testing
}

\author{
Ganye Zhao, Peng Dai, Shanshan Gao, Xuechao Zhao, Conghui Wang, Lina Liu and Xiangdong Kong*
}

\begin{abstract}
Background: Chromosome 18p deletion syndrome is a disease caused by the complete or partial deletion of the short arm of chromosome 18, there were few cases reported about the prenatal diagnosis of $18 p$ deletion syndrome. Noninvasive prenatal testing (NIPT) is widely used in the screening of common fetal chromosome aneuploidy. However, the segmental deletions and duplications should also be concerned. Except that some cases had increased nuchal translucency or holoprosencephaly, most of the fetal phenotype of $18 p$ deletion syndrome may not be evident during the pregnancy, $18 p$ deletion syndrome was always accidentally discovered during the prenatal examination.
\end{abstract}

Case presentations: In our case, we found a pure partial monosomy 18p deletion during the confirmation of the result of NIPT by copy number variation sequencing (CNV-Seq). The result of NIPT suggested that there was a partial or complete deletion of X chromosome. The amniotic fluid karyotype was normal, but result of CNV-Seq indicated a $7.56 \mathrm{Mb}$ deletion on the short arm of chromosome 18 but not in the couple, which means the deletion was de novo deletion. Finally, the parents chose to terminate the pregnancy.

Conclusions: To our knowledge, this is the first case of prenatal diagnosis of $18 p$ deletion syndrome following NIPT.NIPT combined with ultrasound may be a relatively efficient method to screen chromosome microdeletions especially for the $18 p$ deletion syndrome.

Keywords: NIPT, 18p deletion syndrome, Karyotype, CNV-seq, Prenatal diagnosis

\section{Background}

Noninvasive prenatal testing (NIPT) is widely used in the screening of common fetal chromosome aneuploidy including trisomy 21, trisomy 18 and trisomy 13 , due to its high sensitivity and specificity $[1,2]$. However, the common trisomies comprises only approximately $75 \%$ of aneuploidies [3], about $24 \%$ of the reported anomalies would have been missed [4]. Other rare aneuploidies and segmental deletions and duplications should also be concerned. As NIPT is based on the low-coverage whole genome sequencing of maternal plasma cell-free DNA, it can detect all chromosomes actually. Subchromosomal deletions and duplications would also be detected by NIPT [5].

\footnotetext{
* Correspondence: kongxd@263.net

Genetics and Prenatal Diagnosis Center, The First Affiliated Hospital of

Zhengzhou University, Henan Engineering Research Center for Gene Editing of Human Genetic Disease, Erqi District, Zhengzhou, China
}

Chromosome 18p deletion syndrome, a disease caused by the complete or partial deletion of the short arm of chromosome 18, was first reported by Groucy and colleagues in 1963, with an incidence of about 1/50000 in live births [6]. Lack of 18p loss syndrome according to the location and size eventually led to the large difference of clinical features. The main symptoms may involve short stature, low intelligence, special features, language development backwardness, low muscle tone, brain malformation, skeletal deformities, reproductive system dysplasia, kidney or abnormal cardiac birth defects, such as skin hair and serum immunoglobulin A absent or reduced symptoms [7].

There is no specific treatment for the syndrome. The prenatal diagnosis of $18 \mathrm{p}$ deletion syndrome is significant for early management and prevention. As the clinical manifestations of the fetus during the pregnancy vary widely. Majority cases were accidentally diagnosed

(c) The Author(s). 2019 Open Access This article is distributed under the terms of the Creative Commons Attribution 4.0 International License (http://creativecommons.org/licenses/by/4.0/), which permits unrestricted use, distribution, and reproduction in any medium, provided you give appropriate credit to the original author(s) and the source, provide a link to the Creative Commons license, and indicate if changes were made. The Creative Commons Public Domain Dedication waiver (http://creativecommons.org/publicdomain/zero/1.0/) applies to the data made available in this article, unless otherwise stated. 
[8]. The prenatal diagnosis of the syndrome still presents as a challenge because of its untypical clinical presentation [9].

Recently, we found a case of a mid-pregnancy woman with an abnormal chromosome 18p deletion following an aberrant NIPT result. The NIPT results showed a deletion on chromosome X. Karyotype analysis and copy number variation sequencing $(\mathrm{CNV}-\mathrm{Seq})$ were then used to confirm the result of NIPT. Finally, we detected a $7.56 \mathrm{Mb}$ pure deletion at $18 \mathrm{p} 11.32 \mathrm{p} 11.23$ of the fetus.

\section{Case presentation}

A 20-year-old pregnant woman with a single fetus, pregnancy 1 , parturition 0 , gestational age 19 weeks 1 day, was sent to Genetic and Prenatal Diagnostic Center, The First Affiliated Hospital of Zhengzhou University. The woman was $160 \mathrm{~cm}$ tall and weighed $70 \mathrm{~kg}$. The course of her pregnancy was uneventful. Her husband was 25 years old. The couple was both healthy and not consanguineous. The ultrasound findings were normal during the whole pregnancy. NIPT was selected to screen for fetal chromosomal abnormalities. The results suggested that 21-trisomy, 18-trisomy and 13-trisomy were negative, but showed fetal ChrX-, suggesting partial or complete deletion of $\mathrm{X}$ chromosome. Therefore, amniotic fluid was extracted by amniocentesis at 20 weeks of gestation for cell culture analysis of fetal amniotic fluid karyotype and human genome copy number variation
(CNV) was detected by high-throughput sequencing. The result of amniotic fluid karyotype was normal (Fig. 1). The result of CNV-Seq test was seq[hg19]18p11.32p11.23(120000$7,680,000) \times 1$ (Fig. 2), suggesting the heterozygosis deletion of fetus. 18p11.32p11.23 was about $7.56 \mathrm{Mb}$, which contains 24 OMIM genes. In order to further clarify the pathogenicity of the deletion of this segment, the DNA of the couple was extracted from their peripheral blood and cnv-seq test was conducted respectively. The results showed that the couple had no chromosome abnormality (Fig. 3 and Fig. 4), which means the deletion was a de novo mutation in the fetus. Considering all of the above, this deletion was pathogenic. After informing the risk of this syndrome, the pregnant women and her families decided to terminate the pregnancy.

\section{Results}

Peripheral blood $(10 \mathrm{ml})$ was collected in Streck tubes (Streck, USA) from the pregnant woman. Cell free DNA was extracted. Sequencing library preparation and sequencing were conducted according to the instruction. Sequencing was performed using a Next-Seq CN500 Sequencing System (Illumina, USA), with the single-ended $43 \mathrm{bp}$ sequencing protocol. Raw reads were mapped to hg19 reference genome and the uniquely mapped reads were analyzed. We got 4.96 million raw reads and 3.2 million uniMap reads with a fetal fraction of $8.115 \%$. Finally, noninvasive prenatal testing results gave a Z-score of -3.91 for chromosome $\mathrm{X}$ and showed that there was

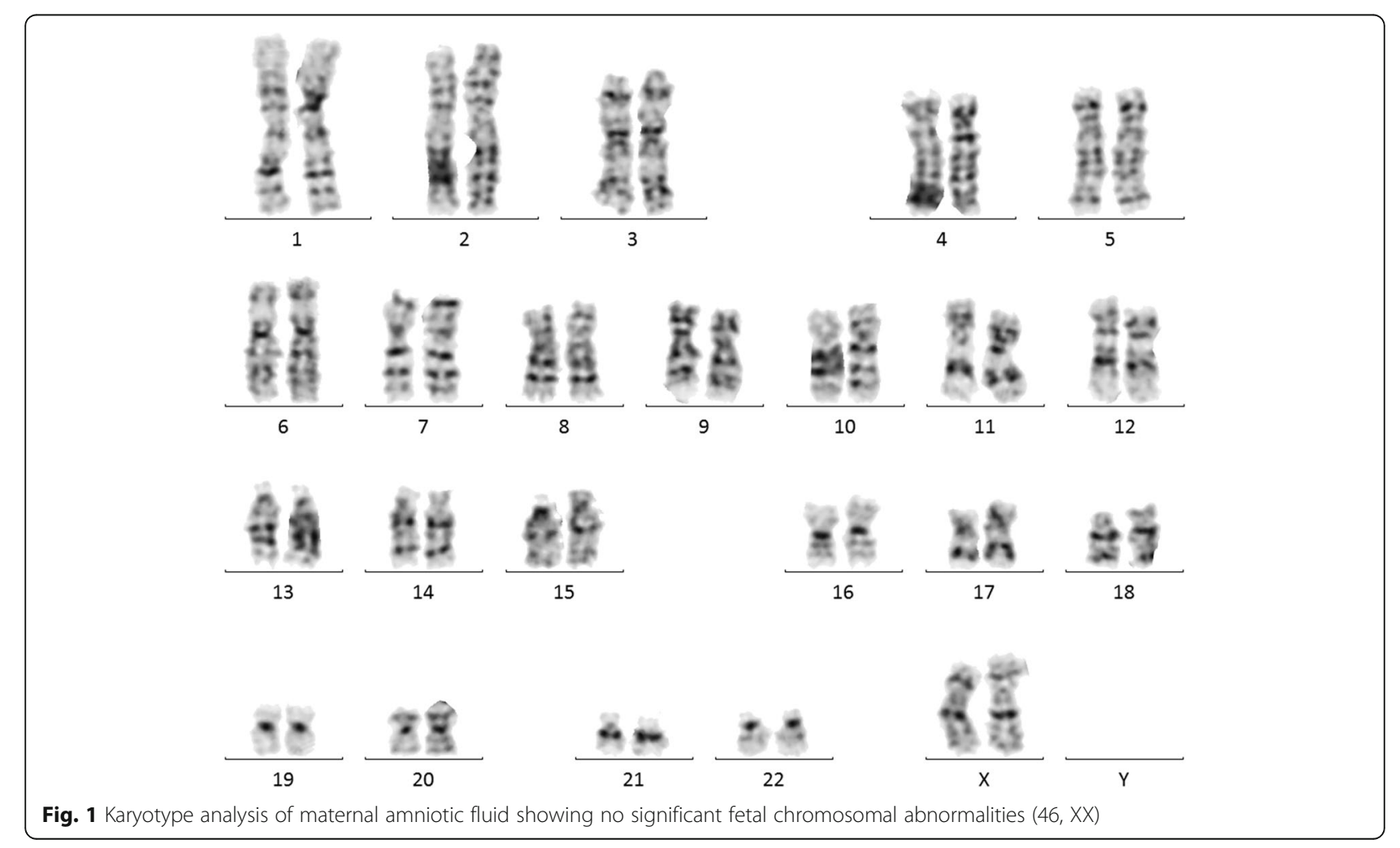




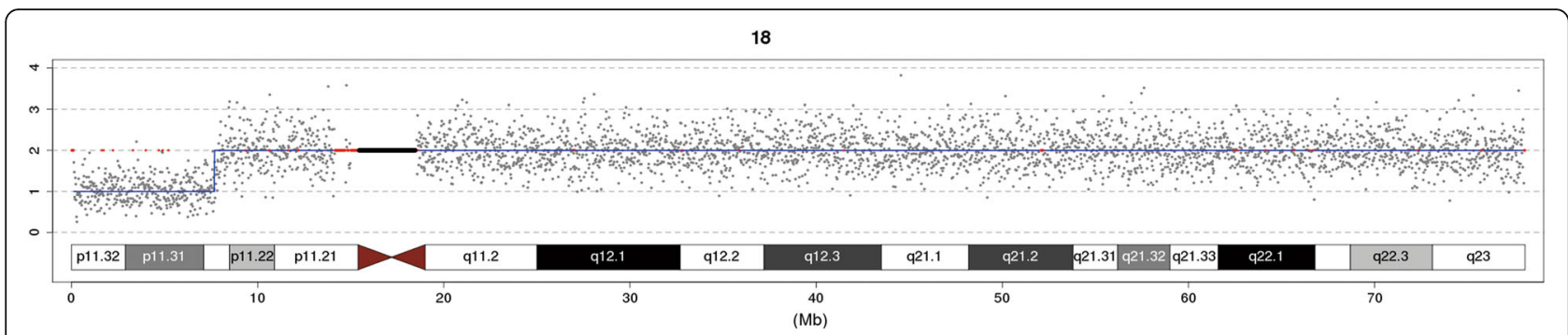

Fig. 2 Copy number variation of maternal amniotic fluid showing that a deletion of 7.56 Mb on chromosome 18p p11.32p11.23(seq[hg19]18 p11.32p11.23 $(120000-7,680,000) \times 1)$

about a deletion of chromosome $\mathrm{X}$. Then amniocentesis was conducted to verify the NIPT results with karyotype analysis and $\mathrm{CNV}$-seq.

The amniocentesis was performed under the guidance of ultrasound, and $20 \mathrm{ml}$ of amniotic fluid was taken. The karyotype analysis of fetal amniotic fluid exfoliated cells was performed. The result of karyotype analysis amniotic fluid showed no obvious abnormalities in fetal chromosome (Fig. 1).

$\mathrm{CNV}$-seq was performed according to standard procedures as previously reported $[10,11]$. In short, DNA extracted from fetal amniotic fluid or uncultured peripheral blood samples was fragmented. Then, sequencing libraries constructed were sequenced on the Next-Seq CN500 platform (Illumina, USA). The results were analyzed using the previously described algorithms [11].

The CNV-Seq analysis results were seq[hg19]18p1 1.32p11.23(120000-7,680,000 $) \times 1$, indicating a deletion of about $7.56 \mathrm{Mb}$ on chromosome $18 \mathrm{p} 11.32 \mathrm{p} 11.23$ (Fig. 2). CNV-Seq analysis of the chromosomes of the couple showed no obvious abnormalities (Fig. 3 and Fig. 4). The inability to detect this microdeletion with the traditional karyotype analysis might be attributable to the low resolution of G-banding.

\section{Discussion and conclusions}

In this case, there was a heterozygosis deficiency of $7.56 \mathrm{Mb}$ in 18p11.32p11.23 $(120,000-7,680,000)$. It contains 24 OMIM genes, including ADCYAP1, ARHGAP28, C18orf42, CETN1, CLUL1, COLEC12, DLGAP1, EMILIN2, ENOSF1, EPB41L3, L3MBTL4, LAMA1, LPIN2, MYL12B, MYOM1, NDC80, PTPRM, SMCHD1, TGIF1, THOC1, TYMS,
USP14YES1 and ZBTB14. There are 12 dose-sensitive genes in the short arm of chromosome 18 [6], 18p11.32p11.23 contains 5 of them: TGIF1, DLGAP1, LAMA1, SMCHD1 and CETN1.The mutation or absence of TGIF1 can cause anencephaly and pituitary dysplasia. The LAMA1 gene is involved in the development of retina, kidney and cerebellum. SMCHD1 gene is associated with facial shoulder brachial muscular dystrophy [12]. Genes associated with autism including DLGAP1 and CETN1 have a great impact on fertility, especially in males. Several patients in the Decipher database were reported as overlapping deletions on 18p with our case. The patient identified as No. 333229 had a 7.03 Mb deletion at chr18:1,835,696-8,861,381 and suffered from language disorders and neurodevelopmental abnormalities. The patient identified as No.328424 had a $4.27 \mathrm{Mb}$ deletion at chr18:136,226-4,409,550 and suffered from congenital microcephaly, global developmental delay and short stature. In conclusion, the fetus was more likely to develop into a $18 \mathrm{p}$ partial deletion syndrome in the future.

The traditional karyotype analysis did not detect the microdeletion due to its low resolution of G-banding. Thanks to the improvements of cytogenetic techniques including chromosome microarray assay (CMA) or CNVSeq, the microdeletions and microduplications would not be omitted.

As with this case, most of patients with $18 \mathrm{p}$ deletion syndrome were de novo deletions [13]. Some prenatal testing including high risk of maternal serum screening, increased nuchal translucency or holoprosencephaly (HPE) may indicate the pure 18p deletion syndrome (Table 1). Manifestations of the 18p deletion syndrome vary greatly from different patients as described above,

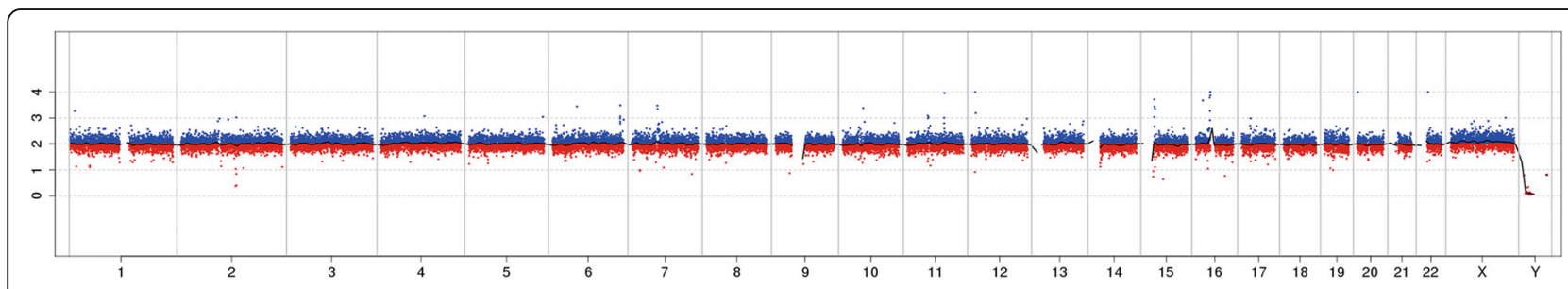

Fig. 3 Copy number variation of the fetus's mother was normal 


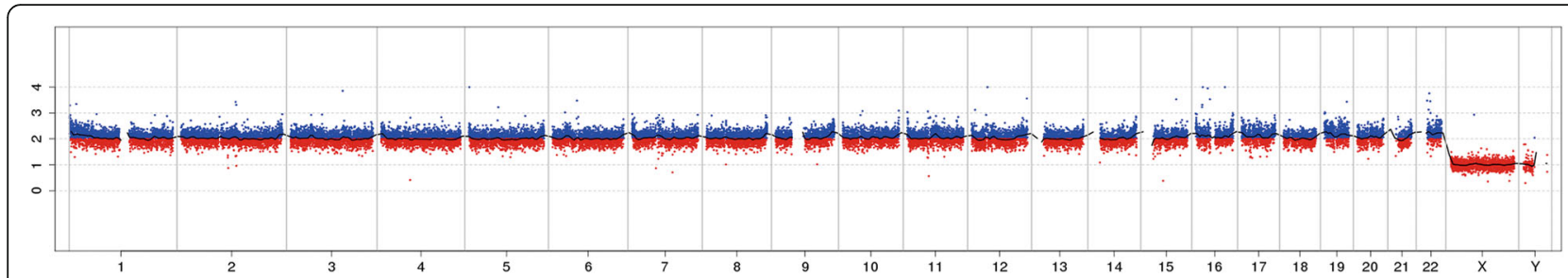

Fig. 4 Copy number variation of the fetus's father was normal

while the pregnancy and delivery were mostly normal. The ultrasound results would be normal during all the whole pregnancy period $[8,13]$, which means the prenatal diagnosis of this syndrome was usually an unexpected finding during amniocentesis [8].

The positive predictive value (PPV) for detecting $45, \mathrm{X}$ was 18.39 to $66.67 \%$ [18-20]. In our center, the PPV for $45, \mathrm{X}$ was $16.13 \%$ (data not published), which needs to be improved. In the all cases of high risk for $45, \mathrm{X}$ in our center, this was the only one case that the result of prenatal diagnosis was pathogenic but the abnormity was discordance with the result of NIPT. The cause of this discordance was not investigated further as it was difficult to get the placenta. A possible explanation may be confined placental mosaicism as fetoplacental mosaicism was a main reason that lead to false positive or false negative results of NIPT [21]. There was a possibility that the placenta has a X chromosome deletion problem, while the fetus has a 18p deletion syndrome.

There are no obvious ultrasound indications or other traditional efficient screening ways to detect the $18 p$ deletion syndrome. NIPT is a very efficient and accurate method for the detection of chromosome aneuploidy, especially for chromosome 13, 18 and 21. Recently, further expansion of NIPT through deeper sequencing has focused on additional screening for microdeletion and microduplications, which had a very successful screening results [22-24]. Prenatal ultrasound of our case was

Table 1 Data of the reported cases of prenatal diagnosis of pure 18p deletion syndrome

\begin{tabular}{|c|c|c|c|c|c|c|c|}
\hline $\begin{array}{l}\text { Gestational } \\
\text { Age }\end{array}$ & Age & $\begin{array}{l}\text { Husband's } \\
\text { Age }\end{array}$ & Methodology & Origin & Deletion & Prenatal Diagnostic Indications & Reference \\
\hline 17 & 39 & 42 & $\begin{array}{l}\text { Karyotype; } \\
\text { FISH }\end{array}$ & de novo & $\begin{array}{l}\text { 46,XY.ish } \\
\text { del(18)(p10pter)(tel18p-, } \\
\text { dim D18Z1) }\end{array}$ & advanced maternal age & [9] \\
\hline 20 & 32 & 38 & $\begin{array}{l}\text { Karyotype; } \\
\text { aCGH }\end{array}$ & de novo & $\begin{array}{l}13.87 \mathrm{Mb} \text { deletions from } \\
18 \mathrm{p} 11.21 \text { to pter }\end{array}$ & $\begin{array}{l}\text { Increased nuchal translucency (INT) }(5.1 \mathrm{~mm}) \text { and a } \\
5.4 \mathrm{~cm} \text { crown-rump length (CRL) at } 12 \text { weeks' } \\
\text { gestation }\end{array}$ & [8] \\
\hline 18 & 32 & NA & $\begin{array}{l}\text { Karyotype; } \\
\text { aCGH }\end{array}$ & de novo & $\begin{array}{l}12.68 \mathrm{Mb} \text { deletions from } \\
\text { 18p11.32-p11.21 }\end{array}$ & $\begin{array}{l}\text { Second trimester maternal serum screening blood } \\
\text { test: a high risk of Down syndrome }(1: 20)\end{array}$ & [8] \\
\hline 18 & 31 & NA & $\begin{array}{l}\text { NIPT; } \\
\text { karyotype; } \\
\text { SNP-array }\end{array}$ & NA & $\begin{array}{l}6.9 \mathrm{Mb} \text { deletions at } \\
18 \mathrm{p} 11.32 \mathrm{p} 11.31 \text { and } 7.5 \\
\text { Mb deletions in } \\
18 \mathrm{p} 11.23 \mathrm{p} 11.21\end{array}$ & $\begin{array}{l}\text { INT from a value of } 3.3 \mathrm{~mm} \text { for } 4.8 \mathrm{~cm} \text { of CRL at } \\
11+4 \text { weeks to } 4.9 \mathrm{~mm} \text { for } 5.91 \mathrm{~cm} \text { of CRL at } 12+ \\
2 \text { weeks of gestation }\end{array}$ & [8] \\
\hline 23 & 24 & 26 & $\begin{array}{l}\text { Karyotype; } \\
\text { FISH; } \\
\text { microarray }\end{array}$ & maternal & $\begin{array}{l}18 \mathrm{Mb} \text { deletion at } \\
18 \mathrm{q} 11.1-\mathrm{p} 11.32\end{array}$ & $\begin{array}{l}\text { A history of abnormal pregnancy, firstpregnancy } \\
\text { ended in a miscarriage in the first trimester; lost the } \\
\text { second pregnancy due to a hydatidiform mole; } \\
\text { Sonography showed congenital foetus } \\
\text { malformation, including fused cerebral } \\
\text { hemispheres, dilatation of the cerebral ventricles, a } \\
\text { single palpebral fissure and proboscis }\end{array}$ & [14] \\
\hline 24 & 29 & 33 & $\begin{array}{l}\text { Karyotype; } \\
\text { FISH; CMA }\end{array}$ & NA & $\begin{array}{l}4.5 \mathrm{Mb} \text { pure } \\
\text { microdeletion at } \\
18 \mathrm{p} 11.32-11.31\end{array}$ & $\begin{array}{l}\text { multiple fetal abnormalities: fetal semilobar } \\
\text { holoprosencephaly, median cleft lip and palate, } \\
\text { arhinia and tetralogy of Fallot }\end{array}$ & [15] \\
\hline 19 & 36 & 34 & $\begin{array}{l}\text { Karyotype; } \\
\text { FISH; aCGH; } \\
\text { qf-PCR }\end{array}$ & de novo & $\begin{array}{l}14.06 \mathrm{Mb} \text { deletion at } \\
18 \mathrm{p} 11.32-\mathrm{p} 11.21\end{array}$ & $\begin{array}{l}\text { advanced maternal age and sonographic findings } \\
\text { of craniofacial abnormalities; Level II ultrasound at } \\
19 \text { weeks of gestation showed HPE and median } \\
\text { facial cleft }\end{array}$ & [16] \\
\hline 13 & 35 & NA & karyotype & de novo & 46,XX,del(18)(p11.2) & $\begin{array}{l}\text { a crown-rump length of } 79 \mathrm{~mm} \text { and an increased } \\
\text { nuchal translucency thickness of } 3.9 \mathrm{~mm}\end{array}$ & [17] \\
\hline
\end{tabular}

Note: aCGH array-based comparative genomic hybridization, FISH fluorescent in situ hybridization, NA not available (absent or unrecorded), NIPT non-invasive prenatal testing, $C M A$ chromosome microarray assay, $q f-P C R$ quantitative fluorescent polymerase chain reaction, INT increased nuchal translucency 
normal, this chromosome deletion would be missed if the woman did not choose NIPT as her prenatal testing. Though, the result of NIPT was discordant with the result of prenatal diagnosis, it gave a clue for the possibility of chromosome abnormity.

Reports of the prenatal diagnosis of 18p deletion syndrome are rare. There are no prenatal diagnosis cases of $18 \mathrm{p}$ deletion syndrome found by NIPT reported previously. A case of de novo 18p inv-dup-del in a Chinese pregnant woman but not her feus was accidentally discovered by the NIPT during her prenatal examination [25]. Our case indicated that NIPT was also useful as a clue to the chromosome microdeletions and microduplications.

In summary, we present the first case of prenatal diagnosis of $18 p$ deletion syndrome following the NIPT. This report shows that NIPT can give clue to chromosome microdeletions. Further expansion of NIPT through deeper sequencing has focused on additional screening for microdeletion and microduplications. NIPT, combined with ultrasound may be a relatively comprehensive screening strategy for fetal 18p deletion syndrome.

\section{Abbreviations}

aCGH: Array-based comparative genomic hybridization; CMA: Chromosome microarray assay; CNV-Seq: copy number variation sequencing; FISH: Fluorescent in situ hybridization; HPE: Holoprosencephaly; INT: Increased nuchal translucency; NA: Not available (absent or unrecorded); NIPT: Noninvasive prenatal testing; PPV: Positive predictive value; qfPCR: Quantitative fluorescent polymerase chain reaction

\section{Acknowledgments}

We thank the subjects and families for participating in the study.

\section{Authors' contributions}

Xiangdong Kong conceived and designed the experiments. Ganye Zhao Peng Dai, Shanshan Gao and Xuechao Zhao performed the experimental work. Ganye Zhao, Conghui Wang and Lina Liu analysed the data. Ganye Zhao and Xiangdong Kong contributed to the writing of the manuscript. All authors read and approved the final manuscript.

\section{Funding}

National Key R\&D Program of China(2018YFC1002206).

\section{Availability of data and materials}

All data generated or analyzed during this study are included in the published article.

\section{Ethics approval and consent to participate}

The authors have no ethical conflicts to disclose, and the institutional ethics. committee approved this study.

\section{Consent for publication}

Patients' parents gave written informed consent.

\section{Competing interests}

The authors declare that they have no competing interests.

Received: 5 September 2019 Accepted: 6 December 2019

Published online: 21 December 2019

\section{References}

1. Allyse MA, Wick MJ. Noninvasive prenatal genetic screening using cell-free DNA. JAMA. 2018;320(6):591-2.

2. Nshimyumukiza L, Menon S, Hina H, Rousseau F, Reinharz D. Cell-free DNA noninvasive prenatal screening for aneuploidy versus conventional screening: a systematic review of economic evaluations. Clin Genet. 2018; 94(1):3-21.

3. Pescia G, Guex N, Iseli C, Brennan L, Osteras M, Xenarios I, et al. Cell-free DNA testing of an extended range of chromosomal anomalies: clinical experience with 6,388 consecutive cases. Genet Med. 2017;19(2):169-75.

4. Lebo RV, Novak RW, Wolfe K, Michelson M, Robinson H, Mancuso MS Discordant circulating fetal DNA and subsequent cytogenetics reveal false negative, placental mosaic, and fetal mosaic cfDNA genotypes. J Transl Med. 2015;13:260

5. Hu H, Wang L, Wu J, Zhou P, Fu J, Sun J, et al. Noninvasive prenatal testing for chromosome aneuploidies and subchromosomal microdeletions/ microduplications in a cohort of 8141 single pregnancies. Hum Genomics. 2019:13(1):14.

6. Hasi-Zogaj M, Sebold C, Heard P, Carter E, Soileau B, Hill A, et al. A review of 18p deletions. Am J Med Genet C Semin Med Genet. 2015;169(3):251-64.

7. Chen CP, Lin SP, Chern SR, Wu PS, Chen SW, Lai ST, et al. A 13-year-old girl with $18 p$ deletion syndrome presenting turner syndrome-like clinical features of short stature, short webbed neck, low posterior hair line, puffy eyelids and increased carrying angle of the elbows. Taiwan J Obstet Gynecol. 2018;57(4):583-7.

8. Qi H, Zhu J, Zhang S, Cai L, Wen X, Zeng W, et al. Prenatal diagnosis of de novo monosomy $18 p$ deletion syndrome by chromosome microarray analysis: three case reports. Medicine (Baltimore). 2019;98(14):e15027.

9. Fogu G, Capobianco G, Cambosu F, Bandiera P, Pirino A, Moro MA, et al. Prenatal diagnosis and molecular cytogenetic characterisation of a de novo 18p deletion. J Obstet Gynaecol. 2014;34(2):192-3.

10. Liang D, Peng Y, Lv W, Deng L, Zhang Y, Li H, et al. Copy number variation sequencing for comprehensive diagnosis of chromosome disease syndromes. J Mol Diagn. 2014;16(5):519-26.

11. Wang J, Chen L, Zhou C, Wang L, Xie H, Xiao Y, et al. Prospective chromosome analysis of 3429 amniocentesis samples in China using copy number variation sequencing. Am J Obstet Gynecol. 2018;219(3): 287 e1-287 e18.

12. Lemmers RJ, van den Boogaard ML, van der Vliet PJ, Donlin-Smith CM, Nations SP, Ruivenkamp CA, et al. Hemizygosity for SMCHD1 in Facioscapulohumeral muscular dystrophy type 2: consequences for $18 \mathrm{p}$ deletion syndrome. Hum Mutat. 2015;36(7):679-83.

13. Turleau C. Monosomy 18p. Orphanet J Rare Dis. 2008:3:4

14. Yin Z, Zhang K, Ni B, Fan X, Wu X. Prenatal diagnosis of monosomy $18 p$ associated with holoprosencephaly: case report. J Obstet Gynaecol. 2017; 37(6):804-6

15. Yi Z, Yingjun $X$, Yongzhen C, Liangying Z, MeijiaoC S. Baojiang, prenatal diagnosis of pure partial monosomy $18 p$ associated with holoprosencephaly and congenital heart defects. Gene. 2014;533(2):565-9.

16. Chen CP, Huang JP, Chen YY, Chern SR, Wu PS, Su JW, et al. Chromosome $18 p$ deletion syndrome presenting holoprosencephaly and premaxillary agenesis: prenatal diagnosis and aCGH characterization using uncultured amniocytes. Gene. 2013;527(2):636-41.

17. Sepulveda W. Monosomy $18 p$ presenting with holoprosencephaly and increased nuchal translucency in the first trimester: report of 2 cases. J Ultrasound Med. 2009;28(8):1077-80.

18. Deng C, Zhu Q, Liu S, Liu J, Bai T, Jing X, et al. Clinical application of noninvasive prenatal screening for sex chromosome aneuploidies in 50,301 pregnancies: initial experience in a Chinese hospital. Sci Rep. 2019;9(1):7767.

19. Garshasbi M, Wang Y, Hantoosh Zadeh S, Giti S, Piri S, Hekmat MR. Clinical Application of Cell-Free DNA Sequencing-Based Noninvasive Prenatal Testing for Trisomies 21, 18, 13 and Sex Chromosome Aneuploidy in a Mixed-Risk Population in Iran. Fetal Diagn Ther. 2019:1-8.

20. $X u Y$, , Chen L, Liu Y, Hao Y, Xu Z, Deng L, et al. Screening, prenatal diagnosis, and prenatal decision for sex chromosome aneuploidy. Expert Rev Mol Diagn. 2019;19(6):537-42.

21. Grati FR, Malvestiti F, Ferreira JC, Bajaj K, Gaetani E, Agrati C, et al. Fetoplacental mosaicism: potential implications for false-positive and false-negative noninvasive prenatal screening results. Genet Med. 2014; 16(8):620-4.

22. Liang D, Cram DS, Tan H, Linpeng S, Liu Y, Sun H, et al. Clinical utility of noninvasive prenatal screening for expanded chromosome disease syndromes. Genet Med. 2019.

23. Srinivasan A, Bianchi DW, Huang H, Sehnert AJ, Rava RP. Noninvasive detection of fetal subchromosome abnormalities via deep sequencing of maternal plasma. Am J Hum Genet. 2013;92(2):167-76. 
24. Wapner RJ, Babiarz JE, Levy B, Stosic M, Zimmermann B, Sigurjonsson S, et al. Expanding the scope of noninvasive prenatal testing: detection of fetal microdeletion syndromes. Am J Obstet Gynecol. 2015;212(3):332 e1-9.

25. Zhu J, Qi H, Cao S, Cai L, Wen X, Tang G, et al. Detection of a rare de novo $18 p$ terminal deletion with inverted duplication in a Chinese pregnant woman. Mol Genet Genomic Med. 2019:e868.

\section{Publisher's Note}

Springer Nature remains neutral with regard to jurisdictional claims in published maps and institutional affiliations.

Ready to submit your research? Choose BMC and benefit from:

- fast, convenient online submission

- thorough peer review by experienced researchers in your field

- rapid publication on acceptance

- support for research data, including large and complex data types

- gold Open Access which fosters wider collaboration and increased citations

- maximum visibility for your research: over $100 \mathrm{M}$ website views per year

At $B M C$, research is always in progress.

Learn more biomedcentral.com/submissions 